\title{
Detecting Melanoma Antigen Family A3 Expression in Solid/Non- Solid Human Tumor
}

\author{
Haoran Jiang \\ Wenzhou Medical University \\ Lihao Zhao \\ Wenzhou Medical University First Affiliated Hospital \\ Han Yang \\ Wenzhou Medical University First Affiliated Hospital \\ Mengjing Zhao \\ Wenzhou Medical University First Affiliated Hospital \\ Yuxia Duan \\ Wenzhou Medical University First Affiliated Hospital
}

Gang Li ( $\sim$ andrewlee0923@wzhospital.cn )

Wenzhou Medical University First Affiliated Hospital https://orcid.org/0000-0002-3859-3281

\section{Primary research}

Keywords: MAGEA3; Cancer/Testis antigen; Prognosis; Outcome

Posted Date: May 6th, 2020

DOI: https://doi.org/10.21203/rs.3.rs-25597/v1

License: (c) (i) This work is licensed under a Creative Commons Attribution 4.0 International License. Read Full License 


\section{Abstract}

Background: MAGEA3 is a member of melanoma antigen family and has been recognized to express in many types of human cancers recently. In spite of the development of cancer vaccine, the prognostic value of MAGEA3 has not been well evaluated, due to the variability of clinical data and lack of clinical trials on the prognostic values.

Method: Studies that evaluated MAGEA3 expression with a follow-up for at least 36 months were selected by searching in PubMed, WOS, Cochrane library, Embase. Published data was recorded and calculated into odds ratios (OR) for mortality in three or five years with Mantel-Haenszel random-effect model.

Results: 11 studies were selected. The median positive rate was 45\%. MAGEA3 always combines with worse survival on three or five years survival. The correlation between MAGEA3 and squamous carcinoma seemed stronger than adenocarcinoma on three-year OS while things got a reverse when it came to five-year OS. Most importantly, we found that all solid tumors originated from endoderm seemed to enjoy a strongest correlation among all the three germ layers.

Conclusion: In this meta-analysis, we found that the expression of MAGEA3 can connect with worse outcome, and it probably can be a predictor for patients' prognosis in clinical practice.

\section{Background}

It has been over 100 years since the similarity between gametogenesis and tumorigeneses being noticed by oncologist, as multiple characteristics were shared during these two processes, from the immortalization of primordial germ cell to the apoptosis inhibition of oncotransformed cells, from the immune evasion that happened in testis to that in cancer cells. Nowadays, 30 years after the discovery of the first cancer and testis shared antigen, it has been a consensus that cancer/testis antigen affects tumor behaviors and could be a risky factor for poor prognosis $(1,2)$.

As one of the most studied CT-X antigen, it has been eventually recognized that MAGEA3 might play a fundamental role in tumorigenesis rather than being a byproduct during malignant proliferation and differentiation. For example, MAGEA3 can demonstrate ubiquitin ligase complex with TRIM28 to guide and activate E3 ubiquitin ligases to degrade AMP-activate protein kinase(3), while the degradation of AMPK can lead to abnormally activation of mTOR signaling which is blamed for being the causes of a large scale of human cancer $(4,5)$. Multiple studies in vitro were also trying to use small molecule like microRNA to inhibit MAGEA3 to inhibit tumor progression and proliferation $(6,7)$. In addition, a few pre-clinical studies detected high-level of MAGE-A3 promoter methylation and MAGEA3 expression correlated with elevated proliferation in vitro in gastric, pancreatic, and cutaneous squamous cell cancer (8-10).

Another phenomenon attracting the attention of oncologists is its identity of cancer-specific antigen. MAGEA3 is always silenced ordinarily in human tissues except sexual gland, indicating that it can be an appropriate target for cancer vaccine and a possible biomarker to detect circulating cancer cell. Recent attention has been focused on several pre-clinical\&clinical trials of MAGEA3 vaccines and its efficiency and safety issue on non-small cell cancer, pancreatic cancer and melanoma $(11,12)$ and this is largely based on the need of improving the outcome of regular therapy and neo-adjuvant chemotherapy. However, despite of the development of anti-MAGEA3 therapy, whether MAGEA3 expression can indicate the appearance of bad prognosis or its value on predicting the outcome of our regular therapy is still unknown due to the variability of clinical data and lack of clinical trials. And it meets the desire to explore multiple tumors to fig out whether MAGEA3 expression is a predictor for worse clinical outcome and bad prognosis.

Here we present a meta-analysis assessing the clinical value of MAGEA3 positive in human cancer. This meta-analysis aimed to provide evidence on whether MAGEA3 can be a predictor for clinical outcome in human cancer and its reliability on this field.

\section{Method}

Preferred reporting items for systematic review and meta-analysis protocols (PRISMA) statement was strictly followed during our metaanalysis being carried out (13).

\section{Identification And Selection Of Studies}

PubMed,WOS, Embase, Cochrane library were searched for studies that evaluated the expression level of MAGEA3 and provided us with access to original data or Kaplan-Meier curves on overall survival (OS). Medical subjects "MAGEA3[Title/Abstract] AND 
cancer[Title/Abstract]" was used. The flowing diagram of PRISMA could be seen at Figure.6. We also screened references which were cited by the selected studies as supplement to simple search. Studies that used download data, could not provide us with enough information expression levels of MAGEA3, measure the potential effect of MAGEA3 vaccine, publication type was meeting conference or letter to editor were excluded. Inclusion criteria was the follow-up length had to be available to provide us with mortality of 36 month, data has to be published in the journals that are included in the Science Citation Index, and publication in English or Chinese. Study selection was based on the association between MAAGEA3 expression and survival. Risk of bias was done with NOS scale and publication bias was evaluated with harbord module.

\section{Data Collection Process}

Information was extracted independently with designed infoextract form. Article basic information and study basic information were recorded. The article basic information included the type of article, publish time, publish journal and impact factors, while the study basic information included cancer type, detected biomarker, patient number, inclusion/exclusion criteria, demographic information, cohort type, subgroup information, follow-up time, control specimen, sample number, detecting method, antibody used, positive standard and rate, number of experimental group and control group, and endpoint. Outcome of interest were three- or five-year survival. In most of the cases, the data were extracted in Kaplan-Meier curves for MAGAE3+ (experimental group) and MAGEAthree- (control group) with GetData Graph Digitizer 2·26. Despite of its possibility of causing deviation, it was the only way we could get all the data we need.

\section{Data Synthesis}

Absolute difference and its $95 \%$ confidence interval on three-year survival rate and five-year survival rate were used to describe the difference on survival between MAGEA3 + group and MAGEAthree- group, while odds ratio and its $95 \% \mathrm{Cl}$ were used to describe the correlation between MAGEA3 expression and survival rates. And our study cohort were divided into six different subgroups including adenocarcinoma, squamouscarcinoam, respiratory cancer, tumor that originating from endoderm, mesoderm and ectoderm. And a number sensitivity tests were prespecified, assessing the tumor type and its origination.

\section{Statistical Analysis}

Review Manager 5.3 (Cochrane Collaboration, Copenhagen, Denmark) was used to combine and calculate the OR and its $95 \% \mathrm{Cl}$ using Mantel-Haenszel random-effect model in order to deal with heterogeneity. Differences between different studies were assessed by $I^{\wedge} 2$ (a method described by Higgins(14)). All the statistical analysis were two-sided and the significance was defined as $\mathrm{P}<0.05$ and the $95 \% \mathrm{Cl}$ of OR should not come across 1.0 .

\section{Result}

\section{Description of Studies}

11 studies were included in our meta-analysis (15-25). Two of them described MAGEA3 expression in head and neck squamous cell carcinoma while two of them described lung cancer and the rest described pancreatic cancer, neuroblastoma, diffuse large B cell lymphoma, multiple myeloma, primary breast cancer, intrahepatic cholagiocarcinoma and bladder cancer for each. For subgroup, three studies were included for adenocarcinoma, five studies were included for squamous cell carcinoma, two studies included for lung carcinoma, five studies included for the cancer originated from endoderm, four for mesoderm and two for ectoderm. 10 studies were available for three-year survival and 10 studies were available for five-year survival. The total number of patient that included in this meta-analysis was 1165 for three-year survival and 1211 for five-year survival. The median positive rate was $45 \%$ among all the 11 studies. The basic information of publications and studies can be seen in (table.1). And the result of evaluating the potential risk of bias and publication bias can be seen in (Figure.1/5). No small study effect was observed in three-year or five-year dimension. P value was 0.657 and 0.714 respectively.

\section{Evaluation And Expression Of Magea3}

A Detecting method and antibody used description can be seen in (Table.1). Due to the limitation of studies number, detection method is kind of variable among all the selected studies. Six studies used immunochemistry to evaluate the expression of MAGEA3, while Six 
studies used polymerase chain reaction to assess, and three of them used combined method to evaluate the expression level of MAGEA3. Due to only two of them reported the exact position of MAGEA3 expression, we could not evaluate whether there was a correlation between the prognosis and MAGEA3 staining. Among all the studies selected the median positive rate was $45 \%$. Two publication about head and neck squamous cell carcinoma, one publication about multiple melanoma (the positive rate among 52 patients was estimated by the total cohort positive rate, as it did not provide specific positive rate among 52 cohort) and one publication about lung cancer has a positive rate for over $50 \%$, while primary breast cancer and intrahepatic cholagiocarcinoma has the lowest positive rate for $10.2 \%$ and $27 \%$ respectively.

\section{Association Between Magea3 Expression And Survival}

The combined analysis of 11 studies showed MAGEA3 expression associated with poor survival no matter on three-year survival and five-year survival. On three-year survival Odds ratio $(O R)=1.97,95 \%$ confidence interval $=1.29$ to $3.02, P=0.002$, and heterogeneity was acceptable $\left(\left.\right|^{\wedge} 2=35 \%\right)$ (Figure.3). On five-year survival, the association seemed stronger, the $\mathrm{OR}=2.33,95 \% \mathrm{Cl}=1.54$ to $3.54, \mathrm{P}<0.001$, $\wedge^{\wedge} 2=40 \%$ (Figure.3). It had to be mentioned that during meta-analysis of three-year survival, main heterogeneity came from neuroblastoma ( $\mathrm{OR}=0.73,95 \% \mathrm{Cl}=0.73$ to 2.55$)$ and multiple myeloma $(\mathrm{OR}=0.51,95 \% \mathrm{Cl}=0.08$ to 3.46$)$, while for five-year survival, it came from one study about head and neck squamous cell carcinoma ( $\mathrm{OR}=0.92,95 \% \mathrm{Cl}=0.40$ to 2.13$)$ (Figure.2/3).

Sensitivity analysis by tumor type suggested that MAGEA3 might be a predictor for mortality of 3 years $(\mathrm{OR}=3.01,95 \% \mathrm{Cl}=1.27$ to 7.14 , $P=0.01)$ but not for mortality of five years $(O R=3.17,95 \% \mathrm{Cl}=0.71$ to $13.60, P=0.13)$ (Table.2). An interesting fact that had to be mentioned was that a study suggested that a higher possibility of MAGEA3 expression in squamous cell carcinoma than adenocarcinoma (23). A similar result was also observed in our meta-analysis: in 388 cases of adenocarcinoma, 70 cases were reported positive for MAGEA3 while in 283 cases of squamous cell carcinoma, 220 were reported positive (Table.4). Then we explored whether there was difference between adenocarcinoma and squamous cell carcinoma. And the data showed that MAGEA3 expression could be a potential indicator for poor prognosis $(\mathrm{OR}=2.4095 \% \mathrm{Cl}=1.31$ to $4.40, \mathrm{P}=0.005)$ on five-year survival while on the dimension of threeyear survival, data showed no statistical significance $(\mathrm{OR}=1.89,95 \% \mathrm{Cl}=0.94$ to $3.81, \mathrm{P}=0.07)$. And when it came to squamous cell carcinoma, thing got reversed, indicating potential was showed in three-year survival but not five-year survival (three-year OS: OR $=2.00$, $95 \% \mathrm{Cl}=1.09$ to $3.68, \mathrm{P}=0.03$; five-year OS:OR $=2.2195 \% \mathrm{Cl}=1.30$ to $3.76, \mathrm{P}=0.10$ ).

As multiple studies had connected cancer/testis antigen expression in tumorigenesis and individual development, we divided all the studies that available for distinguishing the exact origination for its cell origin. Studies were divided into the tumor cell originating from endoderm (five studies), mesoderm (four studies) and ectoderm (two studies). The positive rates were $43.75 \%, 57.72 \%$ and $14.66 \%$ respectively. It was logical as testis originates from mesoderm which indicates a similar biological characteristic and behavior. As MAGEA3 is an antigen mostly expressed in testis in normal human tissues, it became understandable that tumors originated from mesoderm enjoyed the highest positive rate among all three layers. Then we assessed the predict value of MAGEA3 in three different layers originated tumors, and we found the expression of MAGEA3 correlated with poor prognosis only in tumor originating from endoderm (three-year OS: $\mathrm{OR}=2.44,95 \% \mathrm{Cl}=1.44$ to $4.12, \mathrm{P}=0.0009$; five-year OS: $\mathrm{OR}=2.8595 \% \mathrm{Cl}=1.79$ to $4.54, \mathrm{P}<0.00001$ ) rather than mesoderm and ectoderm. And this phenomenon happened on three-year survival and five-year survival both. On the other hand, the correlation between MAGEA3 expression and clinical outcome showed no statistical significance on tumors that originated from mesoderm and ectoderm no matter on the three-year dimension or five-year dimension(M:three-year OS: $\mathrm{OR}=1.78,95 \% \mathrm{Cl}=0.43$ to 7.40 , $\mathrm{P}=0.43$; five-year OS: $\mathrm{OR}=2.30,95 \% \mathrm{Cl}=0.61$ to $8.62, \mathrm{P}=0.22$; $\mathrm{E}$ : three-year OS: $\mathrm{OR}=1.13,95 \% \mathrm{Cl}=0.52$ to $2.46, \mathrm{P}=0.76$; five-year OS: $\mathrm{OR}=1.92,95 \% \mathrm{Cl}=0.77$ to $4.78, \mathrm{P}=0.16)($ Table.3).

\section{Discussion}

In this study, we meta-analysis 11 published data that assessed the correlation between expression level of MAGEA3 and the prognosis of patients for the studies that evaluated MAGEA3 expression with variable methods, due to the deficiency of published data about MAGEA3 and that there was no standard method for detecting the intercellular expression of MAGEA3.

Our result showed that MAGEA3 could be a biomarker for poor prognosis and worse clinical outcome. And this correlation existed no matter on the three-year dimension or five-year dimension, except neuroblastoma and multiple myeloma for three-year, and head and neck squamous cell carcinoma for five-year. As a whole, a stronger correlation was enjoyed on the longer-term dimension. Our sensitivity analysis showed that MAGEA3 was a good predictor for lung cancer on three-year mortality but not on five-year dimension. Difference between adenocarcinoma and squamous cell carcinoma was detected on positive rate and survival correlation, MAGEA3 could be a 
predictor for adenocarcinoma on three-year survival and for squamous cell carcinoma on five-year survival. In addition, we also suggest significant difference among three different layers originated tumors: tumors originated from mesoderm had the highest positive rate while tumors that originated from endoderm enjoyed the strongest correlation between MAGEA3 and poor prognosis.

However a few interesting facts were needed to high lightened: first of all, the abnormal data collected from a study on neuroblastoma actually meet the observation in vitro experiment rather than data error. A study has already showed that using adenovirus to transmit MAGEA3 into glioblastoma cell line U87 was actually able to inhibit invasion and angiogenesis, while multiple onco-pathways like PI3K/AKT and MAPK were also observed to be inhibited (26). However, the exact molecular mechanism of this difference between neurotumors and other tumors is still unknown.

In addition, for the positive rate difference observed between adenocarcinoma and squamous cell carcinoma, the TCGA network had already found difference between adenocarcinoma and squamous cell carcinoma, suggesting a frequent amplification on CCND1, SOX2 and TP63 in squamous cell carcinoma, while ERBB2, VEGFA and GATA4/ 6 in adenocarcinoma(27). Combined with the knowledge that has already been recognized, MAGEA3 mainly targets and degrades AMPK, a protein kinase which is able to detect the intercellular ATP concentration with interaction with ADP and AMP (28)and balance energy metabolism, we could indicate that the difference between adenocarcinoma and squamous cell carcinoma may have a relation to the metabolic difference between both. As multiple studies had suggested that metabolic characteristics varies between different subtypes. For example, although all the tumors showed glucose depletion and lactate increasing, it is more obvious in squamous cell carcinoma rather than adenocarcinoma (29), which could be a possible explanation for the difference expression of MAGEA3: compared to other tumor type, squamous cell tumor is more easily to get into a dilemma of glucose hunger or acidosis. Except for increased glutamic acid consumption which has already been observed, the activated degradation of energy stress sensor may also be a way to escape from apoptosis.

Another fact that was needed to report is that the great difference between tumor origination and MAGEA3. It did not surprise us when we found that mesoderm originated tumor had the highest positive rate for MAGEA3. However, when it came to the prediction field, it was the prognosis of endoderm originated tumor rather than mesoderm originated tumor enjoyed the strongest correlation with MAGEA3. An interesting study observed embryonic stem cells which was deficient for both subunits of a-AMPK and found that the cells exhibited severe defects when differentiation during the process, causing germ layer skewing away from endoderm to ectoderm and endoderm specification blockage via the inhibition of Tfeb, a central transcription regulator during endoderm specification and apoptosis-related factor (30). Can this kind of AMPK-deficiency sensitivity be inherited from fetal to adult and cancer patient? And in that case, whether it is possible that the expression of MAGEA3 can represent a higher heterogeneity between normal cell and cancer cell causing a higher rate of mortality compared to other cancer types? Due to the variability of grades and standard, we could not present a meta-analysis on the correlation between stage and MAGEA3 expression. However, some had already presented MAGEA3 correlated with high tumor stage and poor pathological characteristics $(10,31)$.

This meta-analysis was also with limitation. First of all, as we used published data for analysis, publication bias for positive result was inevitable. Secondly, as we could not attach to the original data, most of our data came from Kaplan-Meier curves. Therefore, systematic error may be included. Thirdly, as there were no standard method for detecting MAGEA3 or standard definition for MAGEA3 positive, substantial heterogeneity maybe exist and could not covered by our model.

In conclusion, our data showed that MAGEA3 expression may associate with poor prognosis in human cancer, especially for cancers that are originated from endoderm. Further data was needed for evaluating the correlation between MAGEA3 and tumor stage.

\section{In Conclusion}

MAGEA3 is an onco-protein according to vitro studies. However, related study outcomes have not been well translated into clinical practice due to variability of published data. Our study showed that MAGEA3 could be a great predictor of prognosis and meet the great need of developing new biomarkers of cancer. In addition, our data showed difference between adenocarcinoma and squamous carcinoma on MAGEA3 expression. We also found tumors that originated from endoderm had the strongest correlation between MAGEA3 and poor prognosis among three layers, which could be a potential direction for further study.

\section{Abbreviations}




\begin{tabular}{ll} 
MAGEA3 & Melanoma Antigen Family A3 \\
\hline CT & Cancer/Testis Antigen \\
\hline $95 \% \mathrm{Cl}$ & $95 \%$ Confidence Interval
\end{tabular}

\section{Declarations}

\section{Author Contribution Statement}

Dr. G Li and YX Duan designed the studies; Dr. LH Zhao and MJ Zhao extracted the data; Dr. H Yang did the analysis and HR Jiang wrote the original passage.

\section{Acknowledgments}

The author wanted to acknowledge Changlin Zou for his sincere help on statistic issues.

\section{Conflict of Interest Statement}

The authors declared no conflict of interest.

\section{Data availability statement}

Data sharing is not applicable to this article as no new data were created or analyzed in this study.

\section{Consent for Publication}

Not applicable.

\section{Ethical Approval and Consent to Participate}

Not applicable.

\section{Funding}

This project was supported by the Medicine and Health Grant from Wenzhou Municipal Science and Technology Bureau (Y20180213) and the Natural Science Foundation of Zhejiang Province (LY20H160009). The funders had no role in the study design, data collection and analysis, decision to publish, or preparation of the manuscript

\section{References}

1. Gibbs ZA, Whitehurst AW. Emerging Contributions of Cancer/Testis Antigens to Neoplastic Behaviors. Trends Cancer. 2018;4(10):701-12.

2. Gordeeva O. Cancer-testis antigens: Unique cancer stem cell biomarkers and targets for cancer therapy. Semin Cancer Biol. 2018;53:75-89.

3. Pineda CT, Potts PR. Oncogenic MAGEA-TRIM28 ubiquitin ligase downregulates autophagy by ubiquitinating and degrading AMPK in cancer. Autophagy. 2015;11(5):844-6.

4. Pineda CT, Ramanathan S, Fon Tacer K, Weon JL, Potts MB, Ou YH, et al. Degradation of AMPK by a cancer-specific ubiquitin ligase. Cell. 2015;160(4):715-28.

5. Mossmann D, Park S, Hall MN. mTOR signalling and cellular metabolism are mutual determinants in cancer. Nat Rev Cancer. 2018;18(12):744-57.

6. Wu F, Liu F, Dong L, Yang H, He X, Li L, et al. miR-1273g silences MAGEA3/6 to inhibit human colorectal cancer cell growth via activation of AMPK signaling. Cancer Lett. 2018;435:1-9.

7. Chen Y, Zhao H, Li H, Feng X, Tang H, Qiu C, et al. LINC01234/MicroRNA-31-5p/MAGEA3 Axis Mediates the Proliferation and Chemoresistance of Hepatocellular Carcinoma Cells. Mol Ther Nucleic Acids. 2020;19:168-78.

8. Xie C, Subhash VV, Datta A, Liem N, Tan SH, Yeo MS, et al. Melanoma associated antigen (MAGE)-A3 promotes cell proliferation and chemotherapeutic drug resistance in gastric cancer. Cell Oncol (Dordr). 2016;39(2):175-86. 
9. Das B, Senapati S. Functional and mechanistic studies reveal MAGEA3 as a pro-survival factor in pancreatic cancer cells. J Exp Clin Cancer Res. 2019;38(1):294.

10. Abikhair M, Roudiani N, Mitsui H, Krueger JG, Pavlick A, Lee J, et al. MAGEA3 Expression in Cutaneous Squamous Cell Carcinoma Is Associated with Advanced Tumor Stage and Poor Prognosis. J Invest Dermatol. 2017;137(3):775-8.

11. Vansteenkiste JF, Cho BC, Vanakesa T, De Pas T, Zielinski M, Kim MS, et al. Efficacy of the MAGE-A3 cancer immunotherapeutic as adjuvant therapy in patients with resected MAGE-A3-positive non-small-cell lung cancer (MAGRIT): a randomised, double-blind, placebo-controlled, phase 3 trial. Lancet Oncol. 2016;17(6):822-35.

12. Lu YC, Parker LL, Lu T, Zheng Z, Toomey MA, White DE, et al. Treatment of Patients With Metastatic Cancer Using a Major Histocompatibility Complex Class II-Restricted T-Cell Receptor Targeting the Cancer Germline Antigen MAGE-A3. J Clin Oncol. 2017;35(29):3322-9.

13. Shamseer L, Moher D, Clarke M, Ghersi D, Liberati A, Petticrew M, et al. Preferred reporting items for systematic review and metaanalysis protocols (PRISMA-P) 2015: elaboration and explanation. Bmj. 2015;350:g7647.

14. Higgins JP, Thompson SG, Deeks JJ, Altman DG. Measuring inconsistency in meta-analyses. Bmj. 2003;327(7414):557-60.

15. Kim J, Reber HA, Hines OJ, Kazanjian KK, Tran A, Ye X, et al. The clinical significance of MAGEA3 expression in pancreatic cancer. Int J Cancer. 2006;118(9):2269-75.

16. Cuffel C, Rivals JP, Zaugg Y, Salvi S, Seelentag W, Speiser DE, et al. Pattern and clinical significance of cancer-testis gene expression in head and neck squamous cell carcinoma. Int J Cancer. 2011;128(11):2625-34.

17. Grau E, Oltra S, Martinez F, Orellana C, Canete A, Fernandez JM, et al. MAGE-A1 expression is associated with good prognosis in neuroblastoma tumors. J Cancer Res Clin Oncol. 2009;135(4):523-31.

18. Olarte I, Martinez A, Ramos-Penafiel C, Castellanos-Sinco H, Zamora J, Collazo-Jaloma J, et al. MAGE-A3 expression is an adverse prognostic factor in diffuse large B-cell lymphoma. Hematology. 2011;16(6):368-72.

19. Atanackovic D, Luetkens T, Hildebrandt Y, Arfsten J, Bartels K, Horn C, et al. Longitudinal analysis and prognostic effect of cancertestis antigen expression in multiple myeloma. Clin Cancer Res. 2009;15(4):1343-52.

20. Ayyoub M, Scarlata CM, Hamai A, Pignon P, Valmori D. Expression of MAGE-A3/6 in primary breast cancer is associated with hormone receptor negative status, high histologic grade, and poor survival. J Immunother. 2014;37(2):73-6.

21. Zhou JX, Li Y, Chen SX, Deng AM. Expression and prognostic significance of cancer-testis antigens (CTA) in intrahepatic cholagiocarcinoma. J Exp Clin Cancer Res. 2011;30:2.

22. Chen X, Wang L, Liu J, Huang L, Yang L, Gao Q, et al. Expression and prognostic relevance of MAGE-A3 and MAGE-C2 in non-small cell lung cancer. Oncol Lett. 2017;13(3):1609-18.

23. Grah JJ, Katalinic D, Juretic A, Santek F, Samarzija M. Clinical significance of immunohistochemical expression of cancer/testis tumor-associated antigens (MAGE-A1, MAGE-A3/4, NY-ESO-1) in patients with non-small cell lung cancer. Tumori. 2014;100(1):60-8.

24. Xylinas E, Cha EK, Khani F, Kluth LA, Rieken M, Volkmer BG, et al. Association of oncofetal protein expression with clinical outcomes in patients with urothelial carcinoma of the bladder. J Urol. 2014;191(3):830-41.

25. Zamuner FT, Karia BT, de Oliveira CZ, Santos CR, Carvalho AL, Vettore AL. A Comprehensive Expression Analysis of Cancer Testis Antigens in Head and Neck Squamous Cell Carcinoma Revels MAGEA3/6 as a Marker for Recurrence. Mol Cancer Ther. 2015;14(3):828-34.

26. Liu XL, Zhao D, Sun DP, Wang Y, Li Y, Qiu FQ, et al. Adenovirus-mediated delivery of CALR and MAGE-A3 inhibits invasion and angiogenesis of glioblastoma cell line U87. J Exp Clin Cancer Res. 2012;31:8.

27. Integrated genomic characterization of oesophageal carcinoma. Nature. 2017;541(7636):169-75.

28. Herzig S, Shaw RJ. AMPK: guardian of metabolism and mitochondrial homeostasis. Nat Rev Mol Cell Biol. 2018;19(2):121-35.

29. Rocha CM, Barros AS, Goodfellow BJ, Carreira IM, Gomes A, Sousa V, et al. NMR metabolomics of human lung tumours reveals distinct metabolic signatures for adenocarcinoma and squamous cell carcinoma. Carcinogenesis. 2015;36(1):68-75.

30. Young NP, Kamireddy A, Van Nostrand JL, Eichner LJ, Shokhirev MN, Dayn Y, et al. AMPK governs lineage specification through Tfebdependent regulation of lysosomes. Genes Dev. 2016;30(5):535-52.

31. Jin X, Pan Y, Wang L, Zhang L, Ravichandran R, Potts PR, et al. MAGE-TRIM28 complex promotes the Warburg effect and hepatocellular carcinoma progression by targeting FBP1 for degradation. Oncogenesis. 2017;6(4):e312.

\section{Tables}

Page 7/12 
Table.1 Characteristics for all the selected studies

\begin{tabular}{|c|c|c|c|c|c|c|c|c|c|c|c|}
\hline Reference & $\begin{array}{c}\text { pancreatic } \\
\text { cancer } \\
\square 14 \square\end{array}$ & $\begin{array}{c}\text { HNSCC } \\
\square 15 \square\end{array}$ & $\begin{array}{l}\text { neuro- } \\
\text { blastoma } \\
\square 16 \square\end{array}$ & $\begin{array}{c}\text { diffuse } \\
\text { large B-cell } \\
\text { lymphoma } \\
\square 17 \square\end{array}$ & $\begin{array}{c}\text { multiple } \\
\text { myeloma } \\
\square 18 \square\end{array}$ & $\begin{array}{l}\text { Primaryi } \\
\text { Breast } \\
\text { Cancer } \\
\square 19 \square\end{array}$ & $\begin{array}{l}\text { intrahepatic } \\
\text { cholagio } \\
\text { carcinoma } \\
\square 20 \square\end{array}$ & $\begin{array}{l}\text { lung } \\
\text { cancer } \\
\square 21 \square\end{array}$ & $\begin{array}{c}\text { lung } \\
\text { cancer } \\
\square 22 \square\end{array}$ & $\begin{array}{c}\text { bladder } \\
\text { cancer } \\
\square 23 \square\end{array}$ & $\begin{array}{c}\text { HNSCC } \\
\square 24 \square\end{array}$ \\
\hline $\begin{array}{l}\text { Publish } \\
\text { Time }\end{array}$ & $5 / 12 / 2005$ & $16 / 8 / 2010$ & $27 / 9 / 2008$ & 2011 & $2 / 3 / 2009$ & $2 / 2014$ & 2011 & $21 / 11 / 2016$ & $26 / 6 / 2013$ & $19 / 8 / 2013$ & $6 / 1 / 2015$ \\
\hline Subtype & $\mathrm{NO}$ & $\mathrm{NO}$ & Gender & $\mathrm{NO}$ & $\mathrm{NO}$ & $\mathrm{NO}$ & $\mathrm{NO}$ & $\mathrm{NO}$ & Aden/Squa & $\mathrm{NO}$ & $\mathrm{NO}$ \\
\hline $\begin{array}{l}\text { Patient } \\
\text { Number }\end{array}$ & 57 & 52 & 47 & 28 & 52 & 362 & 89 & 206 & 80 & 384 & 89 \\
\hline $\begin{array}{r}\text { Inclusion } \\
\text { Criteria }\end{array}$ & YES & YES & YES & YES & YES & YES & YES & YES & YES & YES & YES \\
\hline $\begin{array}{l}\text { Demographic } \\
\text { Characteristic }\end{array}$ & YES & YES & YES & YES & YES & YES & YES & YES & YES & YES & YES \\
\hline Cohort & Multi & Uni & NA & Uni & Uni & Uni & Multi & Uni & NA & Uni & Uni \\
\hline Follow-up & 60 & 53 & 140 & 60 & 120 & 180 & 60 & 80 & 100 & 120 & 60 \\
\hline $\begin{array}{l}\text { Control } \\
\text { Specimen }\end{array}$ & YES & $\mathrm{NO}$ & $\mathrm{NO}$ & $\mathrm{NO}$ & YES & $\mathrm{NO}$ & $\mathrm{NO}$ & YES & $\mathrm{NO}$ & $\mathrm{NO}$ & YES \\
\hline $\begin{array}{l}\text { Sample } \\
\text { Number }\end{array}$ & 57 & 43 & 47 & 28 & 52 & 362 & 89 & 76 & 80 & 384 & 89 \\
\hline $\begin{array}{l}\text { Positive } \\
\text { Stadard }\end{array}$ & $(+/-)$ & $(+/-)$ & $(+/-)$ & $\square+/-)$ & $(+/-)$ & $(+/-)$ & $(+/-)$ & $(+/-)$ & $\begin{array}{c}\square \text { None/ } \\
\text { Weak/ } \\
\text { Moderate } / \text { stro }\end{array}$ & $\begin{array}{c}\text { (None) } \\
\text { /(Weak } \\
\text { derate/Mar }\end{array}$ & $\square+/-)$ \\
\hline Positive Rate & $44 \%(25)$ & 0.51 & $49 \%(23)$ & $39.3 \% \square 11 \square$ & $\begin{array}{l}\text { About } \\
133 / 180\end{array}$ & $\begin{array}{l}10.2 \% \\
(37)\end{array}$ & $27 \%(24)$ & $58 \%(44)$ & $44.4 \%(36)$ & $45 \%(148)$ & $\begin{array}{l}56.2 \% \\
(50)\end{array}$ \\
\hline $\begin{array}{c}\text { Detection } \\
\text { Method }\end{array}$ & $\begin{array}{l}\text { RT-qPCR }] \\
\text { IHC }\end{array}$ & IHC & $\begin{array}{c}\text { RT-qPCR; } \\
\text { SB }\end{array}$ & $\begin{array}{c}\text { RT-qPCR } \square \\
\text { WB }\end{array}$ & RT-PCR & RT-PCR & IHC & IHC & IHC & IHC & RT-PCR \\
\hline Antibody & $\begin{array}{c}\text { Abgent } \\
\text { Inc., San } \\
\text { Diego, CA }\end{array}$ & $\begin{array}{l}\text { 57B (a gift } \\
\text { from G. } \\
\text { Spagnoli, } \\
\text { Basel, } \\
\text { Switzerland) }\end{array}$ & NA & $\begin{array}{c}\text { (Santa Cruz } \\
\text { Biotechnology, } \\
\text { Santa Cruz, } \\
\text { CA, USA }\end{array}$ & $\mathrm{NO}$ & $\mathrm{NO}$ & (clone 57B) & $\begin{array}{c}\text { catalog no. } \\
\text { ab140678; } \\
\text { Abcam, } \\
\text { Cambridge, } \\
\text { UK }\end{array}$ & NA & NA & $\mathrm{NO}$ \\
\hline $\begin{array}{l}\text { Experimental } \\
\text { Number }\end{array}$ & 25 & 22 & 23 & 11 & NA & 37 & 24 & 44 & 36 & 148 & 50 \\
\hline $\begin{array}{l}\text { Control } \\
\text { Number }\end{array}$ & 32 & 21 & 24 & 17 & NA & 325 & 65 & 32 & 44 & 136 & 39 \\
\hline End-Point & OS & OS & OS & OS & OS & OS & OS & OS & OS & OS & OS \\
\hline
\end{tabular}

Table.2 Studies evaluating the expression of MAGEA3 and cancer prognosis

\begin{tabular}{|c|c|c|c|c|c|c|c|}
\hline Study & $\begin{array}{c}\text { Total } \\
\text { number } \\
\text { of } \\
\text { patient }\end{array}$ & $\begin{array}{c}\text { Percentage of patients } \\
\text { with MAGEA3 } \\
\text { expression alive at } 3 \\
\text { years }\end{array}$ & $\begin{array}{c}\text { Percentage of } \\
\text { patients } \\
\text { without } \\
\text { MAGEA3 } \\
\text { expression } \\
\text { alive at } 3 \\
\text { years }\end{array}$ & $\begin{array}{c}\text { Absolute } \\
\text { difference in } \\
\text { survival at } 3 \\
\text { years }(95 \% \mathrm{CI})\end{array}$ & $\begin{array}{l}\text { Percentage of } \\
\text { patients with } \\
\text { MAGEA3 } \\
\text { expression } \\
\text { alive at } 5 \\
\text { years }\end{array}$ & $\begin{array}{c}\text { Percentage } \\
\text { of patients without } \\
\text { MAGEA3 expression } \\
\text { alive at } 5 \text { years }\end{array}$ & $\begin{array}{c}\text { Absolute } \\
\text { difference in } \\
\text { survival at } \\
5 \\
\text { years }(95 \% \mathrm{CI})\end{array}$ \\
\hline HNSCC $\square$ 15ם & 43 & $50.00 \%$ & $57.14 \%$ & $\begin{array}{l}7.14 \square-21.07 \% \text { to } \\
33.78 \% \square\end{array}$ & NA & NA & NA \\
\hline $\begin{array}{c}\text { multiple myeloma } \\
\square 18 \square\end{array}$ & 52 & $92.11 \%$ & $85.71 \%$ & $\begin{array}{l}-6.39 \%(-32.56 \% \text { to } \\
10.11 \%)\end{array}$ & $68.42 \%$ & $85.71 \%$ & $\begin{array}{c}17.29 \% \\
(-11.24 \% \text { to } \\
36.21 \%)\end{array}$ \\
\hline neuroblastoma『16] & 47 & $69.57 \%$ & $62.50 \%$ & $\begin{array}{l}-7.07 \%(-31.80 \% \text { to } \\
19.10 \%)\end{array}$ & $60.87 \%$ & $62.50 \%$ & $\begin{array}{c}1.63 \%(-24.44 \% \\
\text { to } 27.52 \%)\end{array}$ \\
\hline $\begin{array}{c}\text { bladder cancer } \\
\square 23 \square\end{array}$ & 331 & $49.32 \%$ & $60.66 \%$ & $\begin{array}{c}11.33 \%(0.57 \% \text { to } \\
21.77 \%)\end{array}$ & $27.70 \%$ & $53.55 \%$ & $\begin{array}{c}25.85 \% \\
(15.29 \% \text { to } \\
35.51 \%)\end{array}$ \\
\hline HNSCC $\square 24 \square$ & 89 & NA & NA & NA & $56.00 \%$ & $53.85 \%$ & $\begin{array}{c}-2.15 \% \\
(-17.85 \% \text { to } \\
22.11 \%)\end{array}$ \\
\hline $\begin{array}{l}\text { diffuse large B-cell } \\
\text { lymphoma } 17 \square\end{array}$ & 28 & $36.36 \%$ & $82.35 \%$ & $\begin{array}{c}45.99 \%(9.31 \% \text { to } \\
70.08 \%)\end{array}$ & $36.36 \%$ & $82.35 \%$ & $\begin{array}{c}45.99 \%(9.31 \% \\
\text { to } 70.08 \%)\end{array}$ \\
\hline $\begin{array}{c}\text { intrahepatic } \\
\text { cholagiocarcinoma } \\
\square 20 \square\end{array}$ & 89 & $4.17 \%$ & $27.69 \%$ & $\begin{array}{c}23.53 \%(4.90 \% \text { to } \\
35.90 \%)\end{array}$ & $4.17 \%$ & $4.62 \%$ & $\begin{array}{c}0.45 \%(-15.91 \% \\
\text { to } 9.24 \%)\end{array}$ \\
\hline $\begin{array}{c}\text { pancreatic cancer } \\
\square 14 \square\end{array}$ & 57 & $24.00 \%$ & $46.88 \%$ & $\begin{array}{c}22.88 \%(-2.30 \% \text { to } \\
43.72 \%)\end{array}$ & $24.00 \%$ & $43.75 \%$ & $\begin{array}{c}19.75 \%(-5.16 \% \\
\text { to } 40.79 \%)\end{array}$ \\
\hline lung cancer $\square 22 \square$ & 80 & $27.78 \%$ & $43.18 \%$ & $\begin{array}{c}15.40 \%(-5.69 \% \text { to } \\
34.25 \%)\end{array}$ & $22.22 \%$ & $29.55 \%$ & $\begin{array}{c}7.32 \%(-12.20 \% \\
\text { to } 25.37 \%)\end{array}$ \\
\hline $\begin{array}{c}\text { primary breast } \\
\text { cancer } \square 19 \square\end{array}$ & 362 & $86.49 \%$ & $90.77 \%$ & $\begin{array}{c}4.28 \%(-4.14 \% \text { to } \\
18.99 \%)\end{array}$ & $70.27 \%$ & $86.77 \%$ & $\begin{array}{c}16.5 \%(3.58 \% \\
\text { to } 32.88 \%)\end{array}$ \\
\hline lung cancer $\square 21 \square$ & 76 & $38.64 \%$ & $75.00 \%$ & $\begin{array}{c}36.36 \%(13.78 \% \\
\text { to } 53.82 \%) \\
\end{array}$ & $25.00 \%$ & $68.75 \%$ & $\begin{array}{c}43.75 \% \square 21.20 \% \\
\text { to } 60.65 \% \square\end{array}$ \\
\hline
\end{tabular}


Table.3 Subtype analysis dividing studies with adeno/squamous cell carcinoma and the origination of cancer cells

\begin{tabular}{|c|c|c|c|c|}
\hline Type of cancer & $\begin{array}{l}\text { Number of } \\
\text { studies }\end{array}$ & Reference & Pooled OR(95\%CI);P & Subgroup difference $I^{\wedge} 2$ \\
\hline Adenocarcinoma & 3 & $\begin{array}{c}\text { pancreatic cancer } \square 14 \square \\
\text { Primary Breast Cancer } \square 19 \square \\
\text { lung cancer } 22 \square\end{array}$ & $\begin{array}{l}\text { three-year OS: } 1.89(0.94 \text { to } 3.81) ; 0.07 \\
\text { five-year OS: } 2.40(1.31 \text { to } 4.40) ; 0.005\end{array}$ & $\begin{array}{r}0 \% \\
0 \%\end{array}$ \\
\hline Squamouscarcinoma & 5 & $\begin{array}{c}\text { HNSCC } \square 15 \square \\
\text { lung cancer } \square 22 \square \\
\text { bladder cancer } \square 23 \square \\
\text { HNSCC } 24 \square \\
\text { intrahepatic cholagiocarcinoma } \square 20 \square\end{array}$ & $\begin{array}{l}\text { three-year OS:2.00(1.09 to } 3.68) ; 0.03 \\
\text { five-year OS: } 2.21(1.30 \text { to } 3.76) ; 0.10\end{array}$ & $\begin{array}{r}26 \% \\
53 \%\end{array}$ \\
\hline Lung carcinoma & 2 & $\begin{array}{l}\text { lung cancer } \square 21 \square \\
\text { lung cancer } \square 22 \square\end{array}$ & $\begin{array}{l}\text { three-year OS:3.01 (1.27 to } 7.14) ; 0.01 \\
\text { five-year OS:3.12(0.71 to } 13.60) ; 0.13\end{array}$ & $\begin{array}{r}36 \% \\
76 \%\end{array}$ \\
\hline Originated from endoderm & 5 & $\begin{array}{c}\text { bladder cancer } \square 23 \square \\
\text { intrahepatic cholagiocarcinoma } \square 20 \square \\
\text { pancreatic cancer(14) } \\
\text { lung cancer } \square 22 \square \\
\text { lung cancer } \square 21 \square\end{array}$ & $\begin{array}{l}\text { three-year OS:2.44(1.44 to } 4.12) ; 0.0009 \\
\text { five-year OS:2.85(1.79 to } 4.54) ;<0.00001\end{array}$ & $\begin{array}{r}36 \% \\
20 \%\end{array}$ \\
\hline $\begin{array}{l}\text { Originated from } \\
\text { mesoderm }\end{array}$ & 4 & $\begin{array}{c}\text { HNSCC } \square 15 \square \\
\text { multiple myeloma } \square 18 \square \\
\text { HNSCC } \square 24 \square \\
\text { diffuse large B-cell lymphoma } \square 27 \square\end{array}$ & $\begin{array}{l}\text { three-year OS: } 1.78(0.43 \text { to } 7.40) ; 0.43 \\
\text { five-year OS: } 2.30(0.61 \text { to } 8.62) ; 0.22\end{array}$ & $\begin{array}{r}58 \% \\
63 \%\end{array}$ \\
\hline Originated from ectoderm & 2 & $\begin{array}{c}\text { neuroblastoma } 16 \square \\
\text { primary breast cancer } 19 \square\end{array}$ & $\begin{array}{l}\text { three-year OS: } 1.13(0.52 \text { to } 2.46) ; 0.76 \\
\text { five-year OS: } 1.92(0.77 \text { to } 4.78) ; 0.16\end{array}$ & $\begin{array}{l}0 \% \\
44 \%\end{array}$ \\
\hline
\end{tabular}

Table.4 Positive rates in adeno/squamous cell carcinoma

\begin{tabular}{|c|c|c|c|}
\hline Type of cancer & Number of studies & Reference & positive rates \\
\hline Adenocarcinoma & 3 & $\begin{array}{c}\text { pancreatic cancer } \square 14 \square \\
\text { Primary Breast Cancer } \square 19 \square \\
\text { lung cancer } \square 22 \square\end{array}$ & $18.04 \%$ \\
\hline Squamouscarcinoma & 5 & $\begin{array}{c}\text { HNSCC } \square 15 \square \\
\text { lung cancer } \square 2 \square \\
\text { bladder cancer } \square 23 \square \\
\text { HNSCC } 24 \square \\
\text { intrahepatic cholagiocarcinoma(20) }\end{array}$ & $77.73 \%$ \\
\hline
\end{tabular}

\section{Figures}

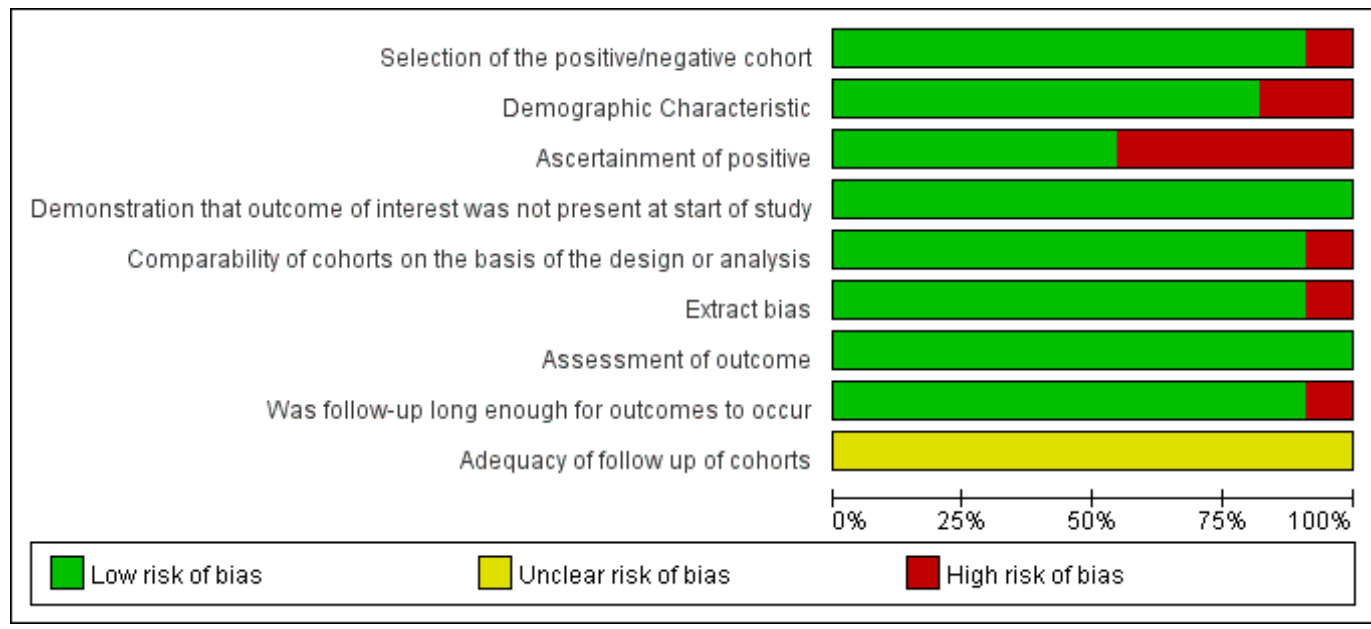

\section{Figure 1}

Quality of included studies were evaluated by NOS (Newcastle Ottawa Scale) and no obvious risk was observed. 


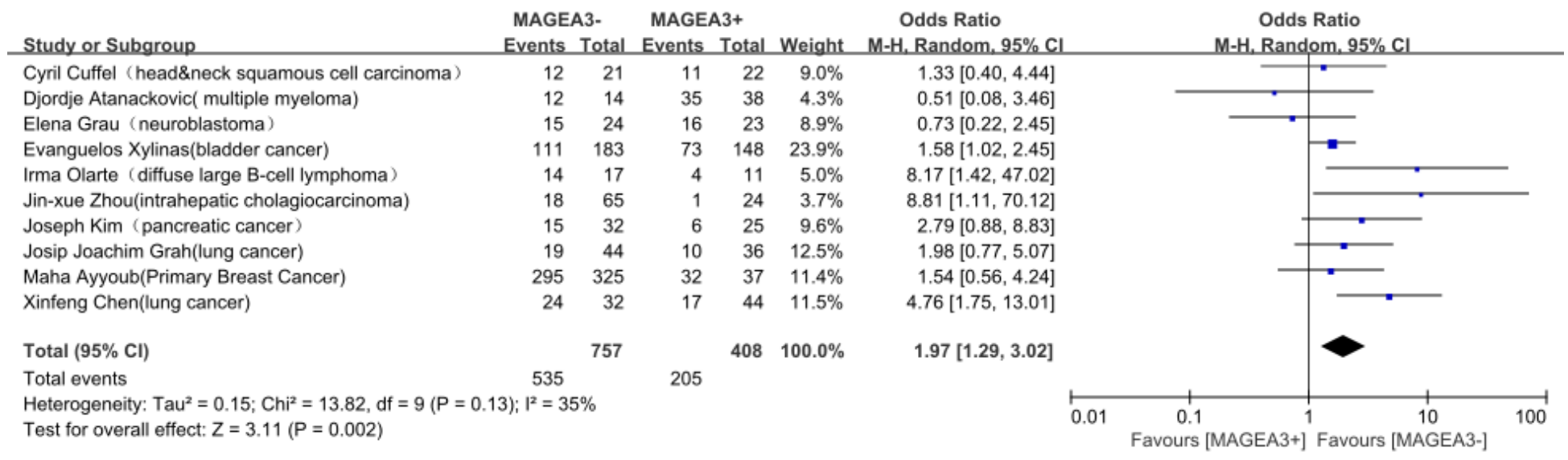

Figure 2

Forest plot for 3-year survival (MAGEA3 negative group versus MAGEA3 positive group). The squares represent the odds ratios of each study, and size of square represents the weight of trails in meta-analysis. The horizontal lines across the square represent $95 \% \mathrm{Cl}$. MantelHaenszel randomized effect model was used in meta-analysis. All the $\mathrm{P}$ value are two-sided.

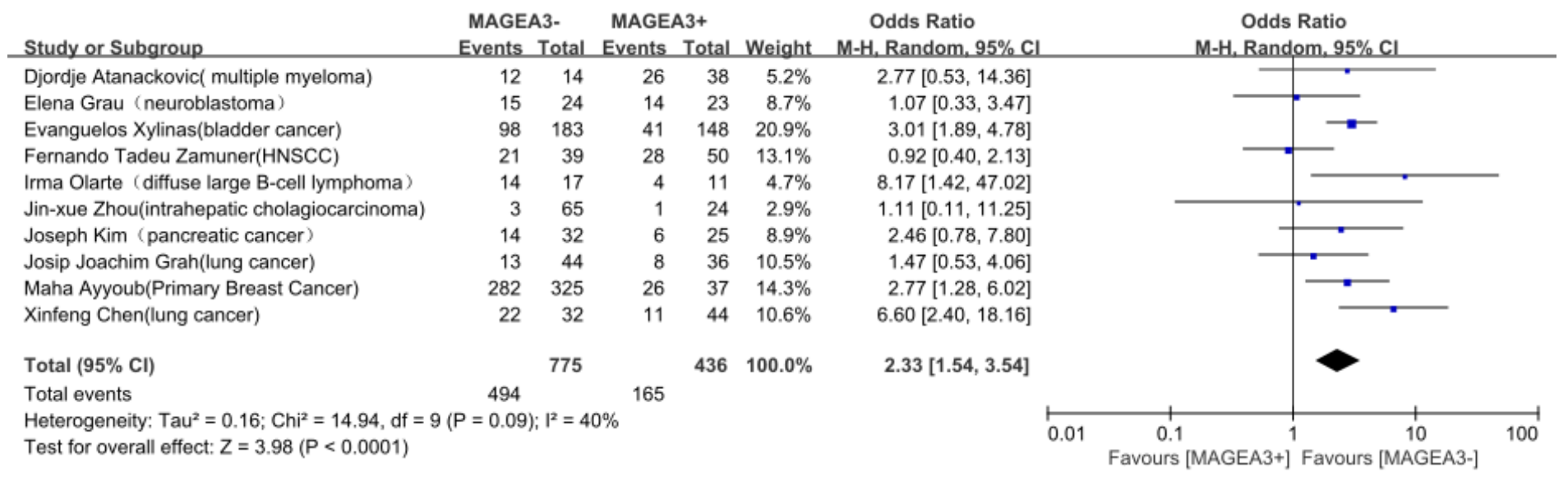

\section{Figure 3}

Forest plot for 5-year survival(MAGEA3 negative group versus MAGEA3 positive group) The squares represent the odds ratios of each study, and size of square represents the weight of trails in meta-analysis. The horizontal lines across the square represent $95 \% \mathrm{Cl}$. MantelHaenszel randomized effect model was used in meta-analysis. All the $P$ value are two-sided.
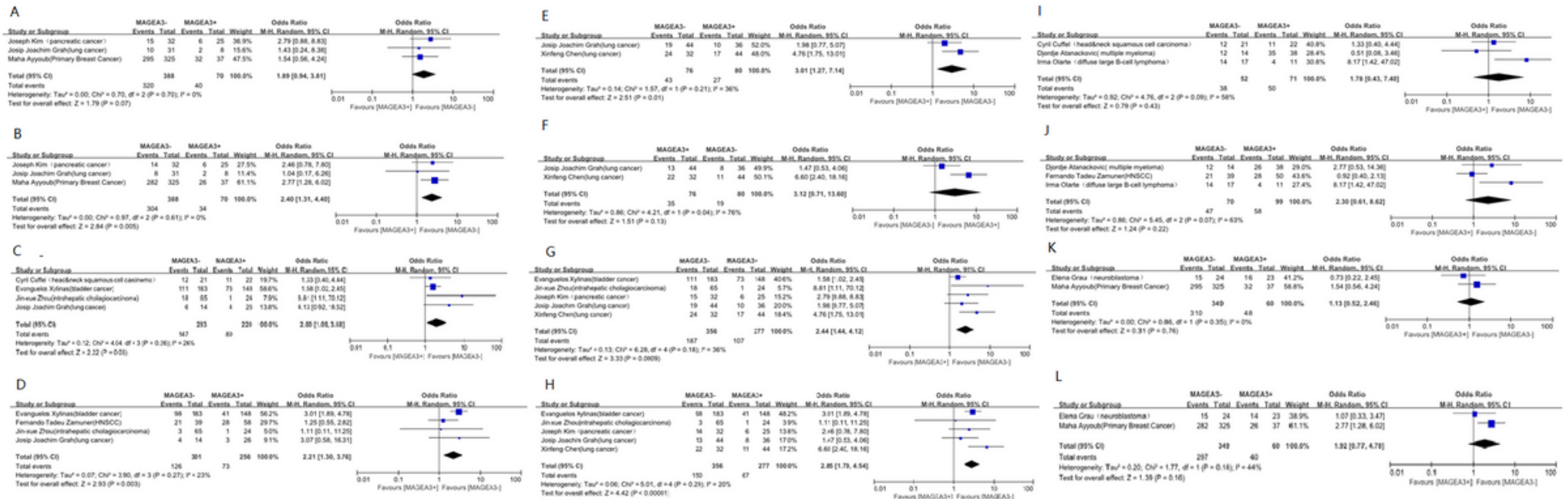

\section{Figure 4}


Sub-analysis divided the whole study cohort into different parts. (A) adenocarcinoma for 3-year survival (B) adenocarcinoma for 5-year survival (C)squamous cell carcinoma for 3-year survival (D)squamous cell carcinoma for 5-year survival (E)lung carcinoma for 3-year survival(F)lung carcinoma for 5-year survival (G)3-year survival for tumors that originated from endoderm(H) 5-year survival for tumors that originated from endoderm(I) 3-year survival for tumors that originated from mesoderm $(\mathrm{J}) 5$-year survival for tumors that originated from mesoderm(K) 3-year survival for tumors that originated from ectoderm $(\mathrm{L})$ 5-year survival for tumors that originated from mesoderm
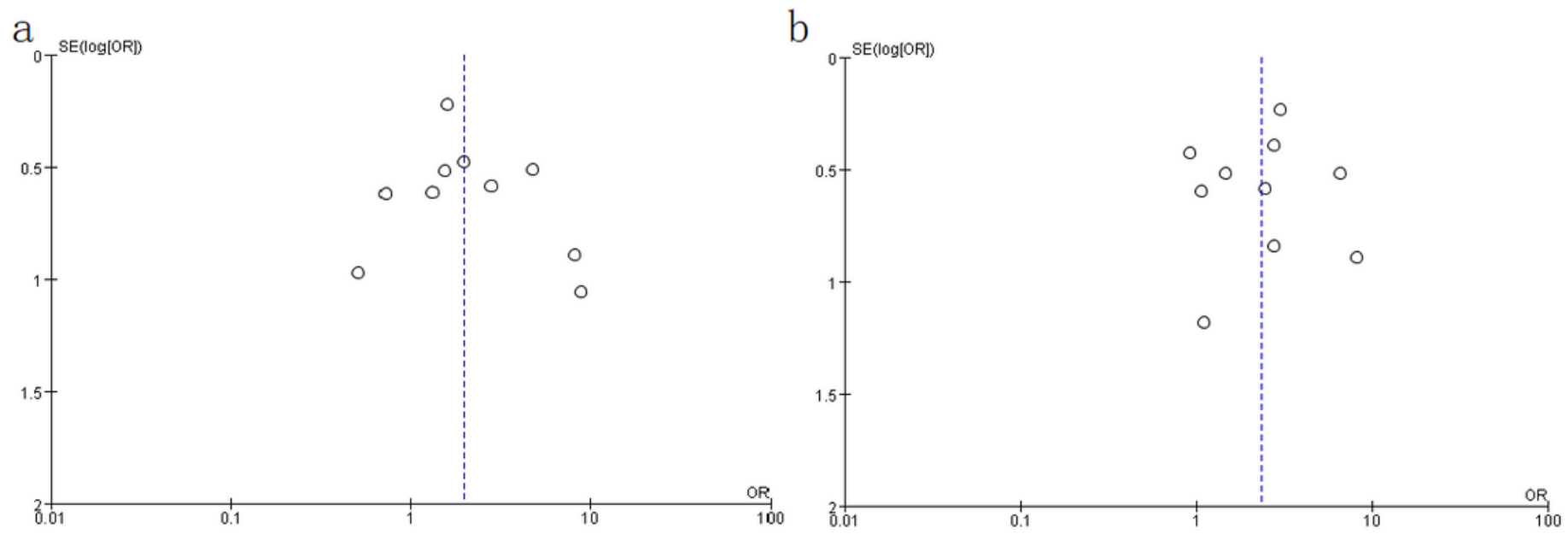

C

d
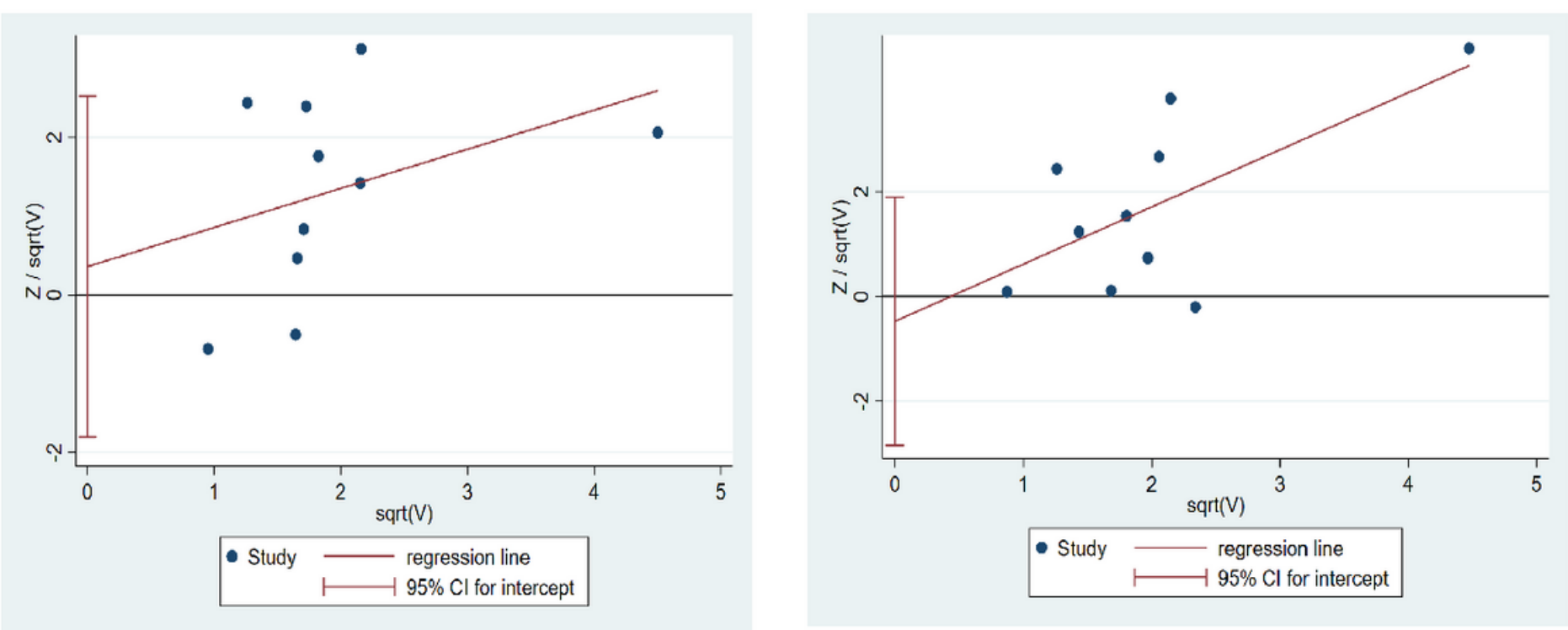

\section{Figure 5}

Funnel plot for total 3-year survival (a) and funnel plot for total 5-year survival (b)were used to evaluate publication bias. Harbord regression model were used to detect small study effect in both 3-year survival (c) and 5-year survival (d). 


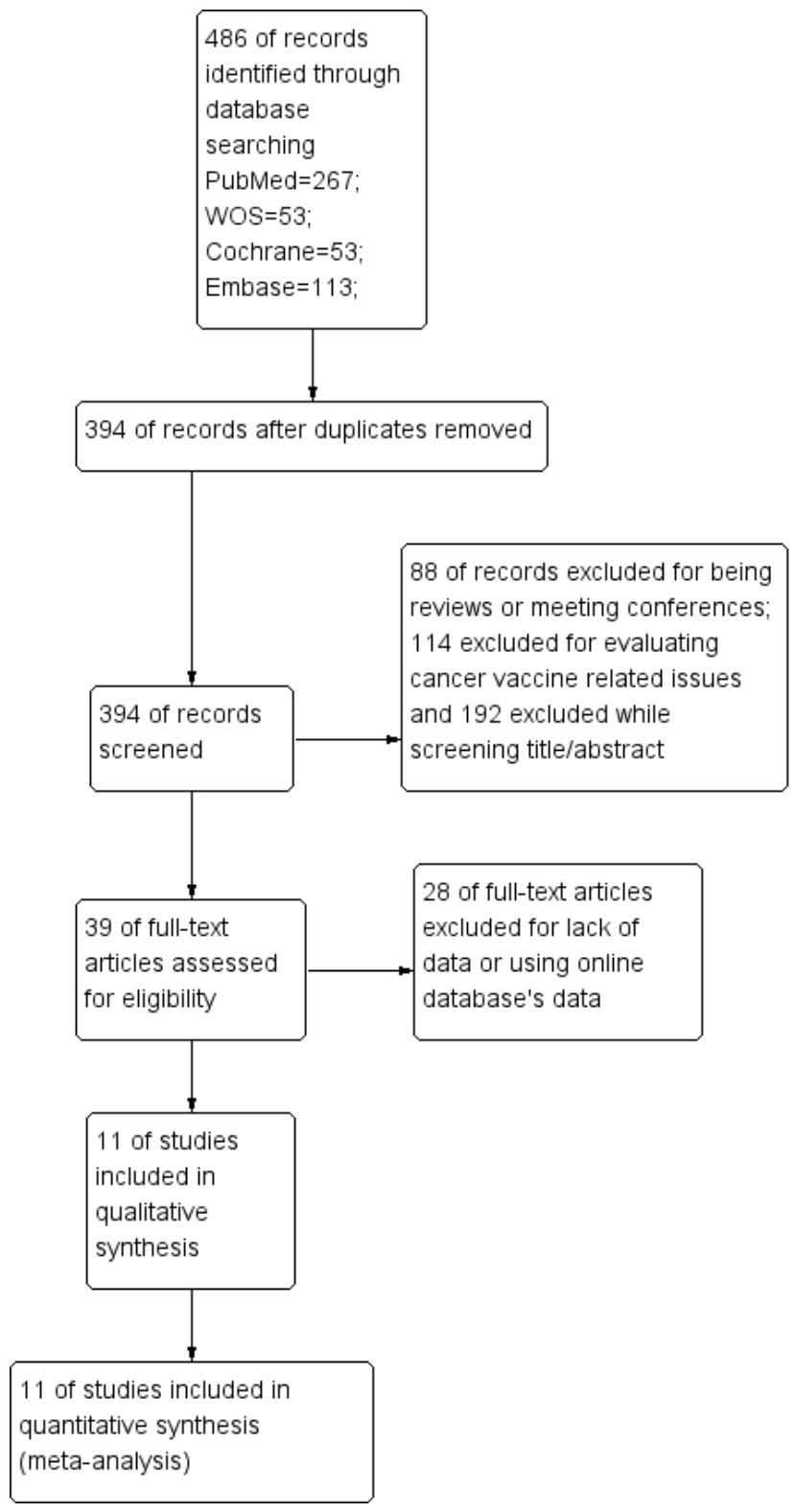

Figure 6

PRISMA protocol was strictly followed during record selection. 